\title{
JUURNAL.RU
}

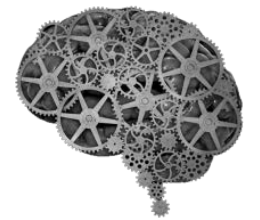

COMPANY GROUP "INTELLEKT"

Боброва Г.А.

Бийский технологический институт Бийск, Россия

doi: 10.18411/lj2016-5-2-04

\section{Разработка и исследование рабочих инструментов ультразвуковых аппаратов для упаковки пищевых продуктов}

Потребности современного общества растут с каждым днем и, зачастую существующие на данный момент технологии не могут удовлетворить их в полном объеме. Поэтому человечеству постоянно приходится находить новые решения тех или иных проблем. С появлением в нашей жизни ультразвуковых технологий (УЗ), в основе которых лежит использование энергии УЗ колебаний, были решены многие технологические задачи. Они помогли не только решить существующие проблемы, но и выявить совершенно новые технологические процессы. Аппараты, основанные на использовании энергии УЗ колебаний, не требуют особых условий эксплуатации, но при этом обладают высокой производительностью и малой потребляемой энергией.

Широкое распространение получил ультразвук и в пищевой промышленности.Особое внимание в данной отрасли уделяется и упаковке различных пищевых продуктов. Одно из важнейших свойств упаковки - это герметичность. Использование ультразвуковых аппаратов для сварки полимеров позволяют достичь высоких характеристик упаковки. Упаковка в полимерные пленки получила большое распространение среди сыпучих продуктов: крупы, сахар, конфеты и т.д.; жидких продуктов: молочные продукты, соусы и т.д. Для герметичности пакета формируется участок, на котором в последствии выполняется шов [1]. При ультразвуковой сваркенеобходимые условия для 
образования соединения создаются в результате механических колебаний ультразвукового преобразователя. Энергия вибрации создает сложные напряжения растяжения, сжатия и среза. При превышении предела упругости соединяемых материалов происходит пластическая деформация в зоне их соприкосновения. В результате пластической деформации и диспергирующегодействия ультразвука происходит удаление адсорбированных пленок жидкости, газов, органическихпленок и поверхностных оксидов, происходит увеличение площади непосредственного контакта, что обеспечивает получение прочного соединения [2]. В большинстве случаев на производстве используется метод импульсной сварки, но он обладает рядом существенных недостатков: не обеспечивает герметизацию при упаковке мелкодисперсных продуктов, например, кофе; не исключает попадания в продукт нестерильного воздуха и т.Д. Поэтому необходим простой и эффективный способ сварки упаковок. В работе [3] описывается процесс ультразвуковой сварки при герметизации упаковки из полимерной пленки. Предложено осуществлять герметизацию пакета двумя поверхностями: прижимной планкой и рабочим окончанием колебательной системы. На рисунке 1 представлен вид ультразвуковой колебательной системы (далее УЗКС), способной обеспечивать сварное соединение длиной 360 мм, шириной 12 мм.

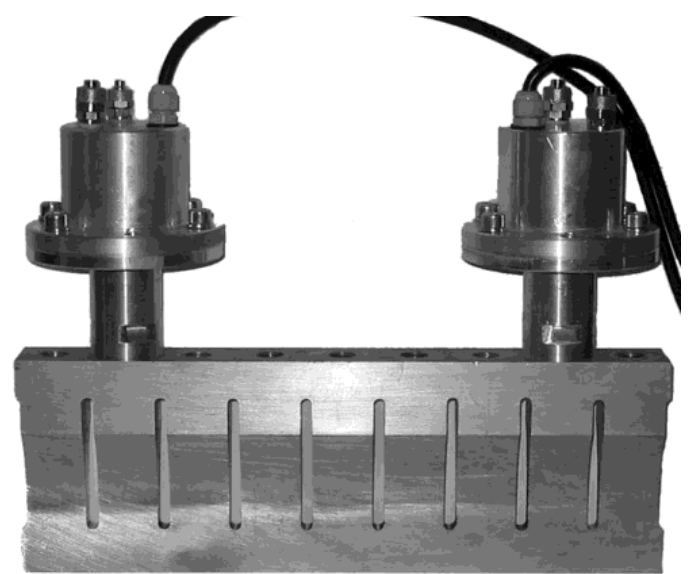

Рисунок 1 - Ультразвуковая колебательная система для обеспечения сварного шва длиной 360 мм

Данные конструкции позволяют осуществлять шовно-шаговую сварку, которая позволяет добиться качественного сварного соединения при упаковке 
сыпучих продуктов в мешки при больших производственных объемах. Данный тип сварки позволяет получить качественное сварное соединение при изготовлении нетканых полотен.

Ультразвуковая шовно-шаговая сварка нетканых материалов позволяет избежать деформаций и разрывов соединений. Также следует отметить, что для обеспечения прочного сварного соединения количество нетермопластичных добавок не должно превышать 65\% от общего числа. [4]

Данные конструкции отвечают всем требуемым параметрам, но имеют один существенный недостаток. Они не могут быть применимы в случаях, когда упаковка имеет сложный контур, а также если требуется сварное соединение шириной более 12 мм. Так же конструировании волноводов такого типа является сложной задачей, так практически невозможно рассчитать параметры аналитическим способом, поэтому зачастую используются программные пакеты, реализующие метод конечных элементов, так в некоторых случаях это единственно возможный способ расчетов.

В настоящее время в пищевой промышленности присутствуют самые различные упаковки, которые поражают своей оригинальностью и сложностью. Сложность упаковки влияет на её герметичность, так как простые методы не могут добиться герметичности упаковки по сложному контуру. Предлагается использовать точечную ультразвуковую сварку, которая позволяет выполнять швы различной сложности, например, сварка блистеров по сложному контуру. На рисунке 3 представлен шов, полученный точечной ультразвуковой сваркой.

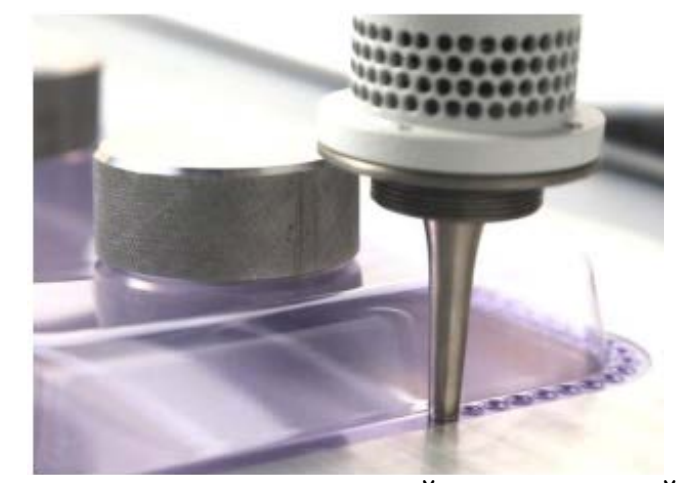

Рисунок 2 - Результат применения точечной ультразвуковой сварки 
Данная ультразвуковая колебательная система имеет вид концентратора. Так существует непрерывный тип сварки, как правило рабочий инструмент такой колебательной системы, также имеет вид концентратора. УЗКС такого типа позволяют формировать качественное сварного соединение практически любой длины, в качестве примера можно привести производство чайных пакетиков [5].

При внедрении круглых крышек в различные пакеты, используемых для хранения сока, молока и других продуктов используют кольцевую сварку. Использование оборудования такого типа позволяет повысить производительность и улучшить качество поставляемого товара.

Изучив достоинства и недостатки различных конструкций ультразвуковых аппаратов, предназначенных для сварки материалов, было выявлено, что исследования являются актуальными на данном этапе развития общества. Поэтому исследования п влиянию УЗ на различные среды необходимы и требуют дальнейшего развития. Так как использование УЗ в пищевой промышленности позволит достичь оптимальных параметров технологического процесса. 


\section{Литература:}

1. Чернов M.Е. Упаковка сыпучих продуктов[Текст]/ M.Е. Чернов М.: ДеЛи,2000. - 164 с.

2. Касаткин, А.Г. Основные процессы и аппараты химической технологии [Текст] /А.Г. Касаткин. - 9-е изд. - М.: Химия,1973. -750 с.

3. Хмелев В.Н. и др. Исследование процесса ультразвуковой сварки при герметизации пищевых продуктов в пакеты из полимерной пленки [Текст]/ В.Н. Хмелев, А.Н. Сливин, Р.В. Барсуков, С.Н. Цыганок, А.В. Шалунов, И.И. Савин, С.В. Левин. - Электронный журнал "Техническая акустика", http://ejta.org, 2005, 17.

4. С.С. Волков Изготовление нетканых материалов посредством скрепления волокнистых холстов ультразвуковой сваркой [Электронный ресурс] Режим доступа: http:/utinlab.ru/articles/ultrazvukovaya-svarka-netkanyhmaterialov

5. Хмелев В.Н. и др. Устройство ультразвуковой сварки изделий по сложному контуру [Текст]/ В.Н. Хмелев, С.С. Хмелев, Д.В. Генне, Д.С. Абраменко, А.Д. Абрамов, М.В. Хмелев, С.В. Левин - Южно-Сибирский научный вестник. - 2014. - №2(6). - С. 159-163. 